\title{
Changes in terrestrial water storage vs. rainfall and discharges in the Amazon basin
}

\author{
Frédéric Frappart (1,2), Guillaume Ramillien (1,2), Josyane Ronchail (3) \\ (1) Université de Toulouse, CNRS, IRD, GET-OMP, 14 Avenue Edouard Belin, \\ 31400 Toulouse, France \\ (2) Groupement de Recherche en Géodésie Spatiale \\ (3) Université Paris Diderot, LOCEAN, Sorbonne Paris Cité, Paris, France
}

Abstract: The present study examines how the interannual variability of rainfall impacts the land water storage in the Amazon basin during the 2003-2010 time span at monthly time-scale using respectively TRMM and GRACE satellite observations. Monthly estimates of GRACE-based terrestrial water storage are compared to (i) TRMM rainfall, (ii) in situ discharges at the outlet of the major sub-basins of the Amazon over 2003-2010 to characterize the redistribution of precipitation on land water. The time-variations of land water storage derived from GRACE are consistent with those of rainfall and discharges at basin and sub-basin scales even, at interannual time-scale (correlation generally greater than 0.7 ). The study of the relationship between these two quantities reveals large differences in terms of rainfall amount, water storage, time delays, resulting of the water transport among the sub-basins of the Amazon. The analysis of GRACE data has permitted to identify the signature of the recent extreme climatic events (droughts of 2005 and 2010, flood of 2009) on the land water storage, in terms of spatial patterns and intensity. These results are in good agreement with what was observed on independent datasets (water levels and discharges, vegetation activity, forest fires, drought index), highlighting the interest of gravimetry from space missions for the characterization of the interannual variability of the terrestrial water storage. 
GRACE data offer the unique opportunity to monitor the hydrological cycle in ungauged basins where reliable observations of rainfall and discharges are missing.

Key words: Terrestrial water cycle, Amazon, GRACE, TRMM

Short Title: TWS vs. rainfall and discharges in the Amazon

Corresponding Author: Dr. Frédéric Frappart

GET-OMP

14 Avenue Edouard Belin, 31400 Toulouse,France

frederic.frappart@get.obs-mip.fr

Phone/fax:(33) 5613329 40/(33) 561332888 


\section{Introduction}

During the past few years, the Amazon basin experienced a succession of extreme hydrological events characterized by two severe droughts in 2005 and 2010, and a large inundation in 2009. Recent studies started to study these phenomenon, their causes and impacts on the Amazonian hydrosystem and ecosystems by analyzing in situ and satellite measurements of water levels, discharges, and rainfall, and relating them to changes in climatic conditions (Marengo et al., 2008a; 2008b; Saleska et al., 2008; Zeng et al., 2008; Philipps et al., 2009; Asner et al., 2010; Espinoza et al., 2011; 2012; Lewis et al., 2011; Marengo et al., 2011; Tomasella et al., 2011; Xu et al., 2011; Marengo et al., 2012; Frappart et al., 2012).

However, these studies give an incomplete view of the terrestrial water cycle as they are based either on the analysis of in situ gauge records of water levels and discharges, or on remotely-sensed observations of rainfall and vegetation activity. Direct information on the impact of extreme events on storage in important hydrological reservoirs of the Amazon basin such as its extensive floodplains and the aquifers is still lacking.

The Terrestrial Water Storage (TWS), which represents an integrated measurement of the water stored in the different hydrological reservoirs, is the sum of the surface water, root zone soil water, snowpack at high latitudes and groundwater. It represents a valuable indicator of the changes that occur in hydrological conditions globally and at basin scales. Nevertheless, TWS is difficult to measure due to the lack of complete in situ observations of the terrestrial hydrological compartments.

The Gravity Recovery And Climate Experiment (GRACE) mission, launched in 2002, detects tiny changes in the Earth's gravity field which can be related to spatio-temporal variations of TWS at monthly or sub-monthly time-scales (see Ramillien et al., 2008; 
Schmidt et al., 2008; Frappart and Ramillien, 2012 for reviews). Previous studies based on GRACE data provide important information on changes in TWS over the Amazon (Crowley et al., 2008; Papa et al., 2008; Chen et al., 2009; 2010; Xavier et al., 2010; Frappart et al., 2012) or its largest tributaries as the Negro River (Frappart et al., 2008; 2011a).

In this study, we propose to analyse the variations of the TWS based on the systematic observations provided by the GRACE mission at basin and sub-basin, and monthly time scales, as well as to correlate them with both rainfall from TRMM and in situ discharge measurements at the outlet of the major sub-basins of the Amazon over the period 20032010. Hence, we are able to characterize the redistribution of the rainfall forcing on TWS. We focus our attention on the interannual variations of the maxima and minima of TWS, and respectively relate them to drought and flood events.

\section{Datasets and methods}

\subsection{TRMM 3B43 monthly rainfall}

In this study, we used the 3B43 TRMM and other data sources monthly rainfall at a spatial resolution of $0.25^{\circ}$ from January 1998 to December 2010. This dataset is obtained by combining satellite information from passive microwave imager (TMI) and precipitation radar (PR) onboard the Tropical Rainfall Measuring Mission (TRMM), a Japan-US satellite launched in November 1997, the Visible and InfraRed Scanner (VIRS) onboard the Special Sensor Microwave Imager (SSM/I), and rain gauge observations. It results from the merging of the 3B42 TRMM-adjusted merged infrared precipitation with the monthly accumulated Climate Assessment Monitoring System or Global Precipitation Climatology Center Rain Gauge analyses (3S45) (Huffmann et al., 1995; 2007). Even if this product overestimates low rainfall, and underestimates large 
rainfall (Aragaõ et al., 2007) and precipitation over mountainous areas (Lavado et al., 2009; Condom et al., 2011), it has been frequently used for large-scale climatic studies over the Amazon basin (Saleska et al., 2007; Philipps et al., 2009; Lewis et al., 2011). It is available on the Goddard Earth Sciences Data and Information Services Center (GES DISC) website: http://daac.gscf.nasa.gov.

\subsection{Level-2 GRACE-derived water mass anomalies}

The Gravity Recovery And Climate Experiment (GRACE) mission, launched in March 2002, provides measurements of the spatio-temporal changes in Earth's gravity field. Several recent studies have shown that GRACE data over the continents can be used to derive the monthly changes of the total land water storage (Ramillien et al., 2008; Schmidt et al., 2008; Frappart and Ramillien, 2012) with an accuracy of $\sim 1.5 \mathrm{~cm}$ of equivalent water thickness when averaged over surfaces of a few hundred squarekilometres. In this study, we used equivalently monthly GFZ, UTCSR and JPL solutions from February 2003 (data are missing for January 2003) to December 2010 in order to analyse the time variations of the water mass changes in the Amazon basin. Unfortunately, the GRACE solution suffer from the presence of an unrealistic high frequency noise corresponding to north-south striping that is caused by orbit resonance during the Stokes coefficients determination and aliasing of not well-modelled shortterm phenomena. To attenuate the noise in the Level-2 GRACE solutions, we used the global solutions post-processing by an Independent Component Analysis (ICA) approach based on the combination of GFZ/UTCSR/JPL solutions of the same monthly period to isolate statistically independent components of the observed gravity field, and 
mainly the continental water storage contribution (Frappart et al., 2010; 2011a). These data can be downloaded at: http://grgs.obs-mip.fr.

\subsection{Delineation of the Amazon sub-basins}

We used the watershed delineation for the Amazon sub-basin systems based on GTOPO30 DEM and a drainage network extracted from JERS SAR images from Seyler et al. (2009), available on the ORE HYBAM portal (http://www.ore-hybam.org) to build masks at $0.25^{\circ}$ of spatial resolution of the largest sub-basins of the Amazon. We decomposed the Amazon drainage system into 8 large drainage areas (larger than $400,000 \mathrm{~km}^{2}$ to be compatible with the low spatial resolution of the GRACE data, see Table 1) - Andean encompassing Ucayali and Marañon flowing from the south, the Japura and the Iça flowing from northwest, Solimões, Mamoré, downstream Madeira, Negro, downstream Amazon, Tapajos, and Xingu basins; they are presented in Figure 1.

\subsection{Time series of monthly discharges}

Time series of monthly discharges for the major sub-basins studied here are obtained from either the Hybam observatory or from the Brazilian water agency or Agencia Nacional de Aguas (ANA). For some stations, data are missing for a few months during 2002-2011. They are linearly interpolated to obtain complete time series of monthly discharges. No data are available in Altamira (Xingu River) after February 2009. As no discharge are measured in Manaus, the time series of river discharge is obtained by difference between the monthly discharges in Jatuarana, the first station in the (Lower) Amazon River, and Manacapuru, the station at the outlet of the Solimões (see Figure 1). Details about discharge stations can found in Table 2. 


\subsection{Palmer Drought Severity Index}

The Palmer Drought Severity Index (PDSI) is the most used index for the characterization of a meteorological drought. It allows the estimate of the cumulative departure (relative to local mean conditions) in atmospheric moisture supply and demand at the surface incorporating antecedent precipitation, moisture supply, and moisture demand into a hydrological accounting system (Dai et al., 2004). It is computed over global land areas using observed or model monthly surface air temperature, and precipitation, plus other surface forcing data for computing potential evapotranspiration from Penman-Monteith approach (the surface net radiation, humidity, wind speed, and air pressure) (Dai, 2011). Here, we use the monthly grids of October 2005 and October 2010 from the monthly self-calibrated PDSI with PenmanMonteith potential evapotranspiration at $2.5^{\circ}$ of spatial resolution over the period 1870 2010 to validate the GRACE-based estimates of TWS during the droughts of 2005 and 2010. They are made available by Dai et al. (2004) at:

http://www.cgd.ucar.edu/cas/catalog/climind/pdsi.html.

\subsection{Time series of monthly rainfall and TWS}

For a given month $t$, the average rainfall (TWS respectively) in a basin with surface area $S$, is simply computed from the rainfall (respectively the water heights) $\delta h_{j}$, with $j=1$, $2, \ldots$, expressed in $\mathrm{mm} / \mathrm{month}$ (respectively $\mathrm{mm}$ of equivalent water height) inside $S$, and the elementary surface $R_{e}^{2} \sin \theta_{j} \delta \lambda \delta \theta$ (Ramillien et al., 2006):

$$
\delta h(t)=\frac{R_{e}^{2}}{S} \sum_{j \in S} h\left(\lambda_{j}, \theta_{j}, t\right) \sin \theta_{j} \delta \lambda \delta \theta
$$


where $\lambda_{j}$ and $\theta_{j}$ are longitude and co-latitude, $\delta \lambda$ and $\delta \theta$ are the grid steps in longitude and latitude (generally $\delta \lambda=\delta \theta)$, and $R_{e}$ the mean radius of the Earth $(6371 \mathrm{~km})$.

\subsection{STL decomposition}

The time-series of monthly rainfall and TWS $(h(t))$ are decomposed into series into trend $(T(t))$, seasonal $(S(t))$, and residual $(R(t))$ components using the non-parametric STL approach (Cleveland et al., 1990):

$$
h(t)=T(t)+S(t)+R(t)
$$

The STL method, based on locally weighted regression, is a robust and computationally efficient approach commonly used for detecting non-linear patterns in trend estimates. This iterative method consists of two recursive procedures nested one into another, and referred as inner and outer loops. The trend and seasonal estimates are recursively determined into the inner loop using smoothing techniques such as locally weighted regression and low pass filtering (consecutive averages) at each iteration. Robustness weights are estimated in the outer loop are used in the next run of the inner loop to reduce the influence of outliers in the computation of the trend and seasonal signals. This method was recently applied to the GRACE data for the characterization of the interannual variability of the Greenland mass balance (Bergmann et al., 2012). The values of six parameters has to be chosen to start the STL decomposition: the number of observations $(N)$, the number of observations for each annual cycle $\left(n_{p}\right)$, the number of passes in the inner $\left(n_{i}\right)$ and in the outer $\left(n_{o}\right)$ loops, the smoothing parameters for the lowpass filter $\left(n_{l}\right)$, the seasonal component $\left(n_{s}\right)$, and the trend $\left(n_{t}\right)$. The two first are given by the length of the time series and its sampling frequency. Here, $N=96$ and $n_{p}=12$. To reach the convergence of the method, we chose $n_{i}=5$ and $n_{o}=5$ following Cleveland et al. 
(1990) suggestions. The low-pass smoothing parameter is chosen to be equal to the least odd integer greater than or equal to $n_{p}$. In this study, $n_{l}=13 . n_{s}$ is an odd integer that has to be greater than 6 . Because of the monthly resolution of the datasets, we chose $n_{s}=13$. Finally, $n_{t}$ needs to be greater or equal than the least odd integer respecting this threshold:

$$
n_{t} \geq \frac{1.5 n_{p}}{1-\frac{1.5}{n_{s}}}
$$

Here, we chose $n_{s}=51$.

\subsection{Standardized anomaly indexes of rainfall and TWS}

The rainfall standardized anomaly index was defined by Lamb (1982) to study long term rainfall variations:

$$
I_{R}(t)=\frac{1}{n} \sum_{i=1}^{n} \frac{R\left(\lambda_{i}, \theta_{i}, t\right)-\overline{R\left(\lambda_{i}, \theta_{i}\right)}}{\sigma\left(R\left(\lambda_{i}, \theta_{i}\right)\right)}
$$

where $R\left(\lambda_{i}, \theta_{i}, t\right)$ is the annual or the seasonal rainfall at grid element of coordinates ( $\left.\lambda_{\mathrm{i}}, \theta_{i}\right)$ for year $t, \overline{R\left(\lambda_{i}, \theta_{i}\right)}$ and $\sigma\left(R\left(\lambda_{i}, \theta_{i}\right)\right)$ are the annual or the seasonal average and standard deviation over the reference period for a grid element $\left(\lambda_{\mathrm{i}}, \theta_{i}\right)$, respectively, and $n$ is the total number of grid elements used in the computation.

In this study, this index was computed at regional, and pixel scale using the 3B43 monthly TRMM-derived gridded rainfall over the 2003-2010 period for the wet and dry seasons. Regions (north and south Amazonia), and seasons (wet and dry) were defined following Marengo et al. (2011): north Amazonia (respectively south Amazonia) corresponds to latitude greater (respectively lower) than $7.5^{\circ} \mathrm{S}$, and the rainy season lasts from February to May (FMAM) in the north and from December to March (DJFM) whereas the dry season lasts from July to October (JASO) for both north and south. 
Similarly, the TWS standardized anomaly index was defined using the GRACE data:

$$
I_{T W S}(t)=\frac{1}{n} \sum_{i=1}^{n} \frac{\operatorname{ext}\left(T W S\left(\lambda_{i}, \theta_{i}, t\right)\right)-\overline{\operatorname{ext}\left(T W S\left(\lambda_{i}, \theta_{i}\right)\right)}}{\sigma\left(\operatorname{ext}\left(T W S\left(\lambda_{i}, \theta_{i}\right)\right)\right)}
$$

where $\operatorname{ext}\left(\operatorname{TWS}\left(\lambda_{i}, \theta_{i}, t\right)\right)$ is the extremum (i.e., minimum or maximum) of TWS at grid element of coordinates $\left(\lambda_{\mathrm{i}}, \theta_{i}\right)$ for year $t, \overline{\operatorname{ext}\left(T W S\left(\lambda_{i}, \theta_{i}\right)\right)}$ and $\sigma\left(\operatorname{ext}\left(\operatorname{TWS}\left(\lambda_{i}, \theta_{i}\right)\right)\right)$ are the average and standard deviation of the extremum of TWS over the reference period for a grid element $\left(\lambda_{\mathrm{i}}, \theta_{i}\right)$.

\section{Results and discussion}

3.1 Basin and regional scale changes in rainfall and TWS

Time series of monthly average rainfall from TRMM 3B43 and GRACE-derived TWS over 2003-2010, as well as the corresponding interannual trends computed using the STL approach are respectively presented on figures $2 \mathrm{a}$ and $2 \mathrm{~b}$ for the Amazon basin and on figures 3 and 4 for its 8 major sub-basins. They are characterized by a large seasonal cycle at basin-scale that reaches $\sim 400 \mathrm{~mm}$, but also exhibit important interannual variability corresponding to the extreme climatic events that occurred during the past few years. The signature of the drought of 2010 clearly appears on the interannual trend profiles of TWS and rainfall at basin-scale, but not the ones of the drought of 2005 and the flood of 2009 (Figures 2a and 2b). The exceptional drought of 2010 is caused by a huge decrease in the monthly rainfall occurring between 2008 and 2010 (-175 mm during this period).

Large contrasts are observed among the sub-basins, both in terms of amount of rainfall and amplitudes of TWS, and interannual variations (Figures 3 and 4). Decreases of 
rainfall starting in 2004 and responsible for the drought of 2005, are observed in the interannual trends on the south-central (Solimões and Lower Madeira) and south-eastern parts (Lower Amazon, Tapajos, Xingu), whereas a large decrease starting in 2009 is present over all the sub-basins, causing the drought of 2010 (Figure 4). On the contrary, the increase of rainfall that started in 2008 was responsible for the flood of 2009 in all the sub-basins with exception of the Andean and the Negro sub-basins. $I_{R}$ was computed from the TRMM 3B43 monthly rainfall for both north $\left(7.5^{\circ} \mathrm{S}<\right.$ latitude < $\left.5^{\circ} \mathrm{N}\right)$ and south Amazonia $\left(20^{\circ} \mathrm{S}<\right.$ latitude $\left.<7.5^{\circ} \mathrm{S}\right)$ during the wet (FMAM in the north and DJFM in the south) and dry (JASO for both regions) over the period 2003-2010 (Figure 5). Similarly, $I_{T W S}$ was computed from GRACE solutions for maximum and minimum of the water cycle (Figure 6). They both help in determining the intensity of the event. The drought of 2005, which affected an area of 1.9 million $\mathrm{km}^{2}$ (Lewis et al., 2011), is characterized by large negative values of the $I_{R}$ in south Amazonia for both seasons, and a smaller negative $I_{R}$ value in north Amazonia during the dry season, as well as large negative values of $I_{T W S}$ for north and south Amazonia during the low waters. Above normal rainfall observed over north and south (respectively north) Amazonia are responsible for the flood of 2006 (2009), characterized by a large positive anomaly of $I_{T W S}$ during high waters. The drought of 2010 (affecting an area of about 3.0 million $\mathrm{km}^{2}$ ), with the largest negative anomalies of both $I_{R}$ and $I_{T W S}$ during the dry season for north and south Amazonia over the observation period, can be considered as widespread and extreme climatic events.

For all the sub-basins located or mostly located in Southern Amazonia, the minimum of TWS anomaly occurs in September-October 2010, whereas for the Negro and the Lower Amazon basins, located in Northern Amazonia, it occurs in December 2009- 
January 2010. This is consistent with the record of in situ gauge stations in Tamshiyacu - upper Solimões (Espinoza et al., 2011) and Manaus Negro (Marengo et al., 2011), assuming that surface storage represents a large part of the TWS. This assumption is confirmed by previous studies showing that surface water storage as estimated using remote sensing techniques represents a half of TWS in the Negro basin (Frappart et al., 2008; 2011a), and in the whole Amazon basin (Frappart et al., 2012). It also agrees well with previous analysis of GRACE data and GLDAS/NOAH outputs showing that (i) the TWS is equally partitioned between surface and sub-surface reservoirs and soil water (Han et al., 2009), and (ii) modeling results from ensemble hydrological simulations with river routing which found that surface water and shallow groundwater represent $73 \%$ of the TWS in the Amazon basin (Kim et al., 2009). Contrary to what can be seen on rainfall, the signature of the other large climatic events does not appear so clearly neither on the TWS time-series nor on the associated interannual trends at sub-basin scale.

Monthly rainfall are highly correlated to monthly anomalies of TWS at basin and subbasin scales ( $r>0.78$ for all the basins, except for the Andean basins where $r=0.68)$ due to large seasonal variations (Table 3). The lower correlation value in the case of the Andean basins can be accounted for the poor accuracy of TRMM 3B43 product over mountainous areas located in these basins (Lavado et al., 2009; Condom et al., 2011). Changes in rainfall induce variations in TWS with a delay of two months for most of the sub-basins, except the Negro River basin where the time lag is of one month (Table 3), and a delay of two or three months at interannual time-scale. These delays characterize the transport processes in the hydrographic network slowed down by the residence of water into the extensive floodplains present in the Amazon basin. The 
phase differences between monthly rainfall and TWS anomalies are presented in Figure 7. The hydrological regime of the sub-basins is characterized by a strong hysteresis. For all the basins mostly located in the southern hemisphere (Figures $7 \mathrm{a}$ to $\mathrm{f}$ ), the minimum (respectively maximum) of the rainfall is from July to September (respectively from January to March). For the Negro and the Lower Amazon basins, located on both hemispheres the temporal location of extrema is more variable. Minima (respectively maxima) are occurring between September and February (April and July) in the Negro basin, and between August and November (February to May) in the Lower Amazon basin (Figures $7 \mathrm{~g}$ and $\mathrm{h}$ ).

A similar behaviour is observed 2 months later on the TWS for all the sub-basins (except the Negro basin where the time-lag is of 1 month). These hysteresis cycles present a strong interannual variability, especially in the basins with extensive floodplains (i.e., downstream part of the Andean basins, Solimões, Mamoré, Negro, Lower Amazon) where time residence of the water in the floodplains is highly dependent on the interannual variability of the rainfall, and in the Andean basins where the rainfall is not correctly estimated over mountainous areas.

A generally good agreement is found between TWS and river outflow-inflow at basin scale $(R \geq 0.8$ except for the Negro basin where $R=0.72$, see Table 4$)$. This lower agreement is maybe due to the fact that river discharges at the outlet of the Negro are not measured but too simply reconstructed as the difference between discharges measured in Jatuarana (inlet of the Lower Amazon) and Manacapuru (outlet of the Solimões), generating uncertainties. TWS precedes river discharge of one month for the whole basin and two months for the Solimões (i.e., the major tributary to the Amazon), 
is in phase for the Andean basins, the Lower Madeira, and the Xingu, is delayed of one month for the Negro, the Tapajos, and the Lower Amazon (Table 4).

At interannual time-scale, high correlations are also observed for most of the sub-basins ( $\mathrm{R} \geq 0.85$ and $\mathrm{R}=0.76$ for the Negro basin), except for the Lower Amazon $(\mathrm{R}=0.63)$ and the Lower Madeira $(\mathrm{R}=0.59)$ (Table 4 and Figure 8). The lower correlations for these two latter sub-basins can be explained the locations of the discharge stations, several hundred kilometres downstream the inlet of the Lower Madeira in the case of Porto Velho, and 1,500 km upstream the mouth of the Amazon in the case of Obidos. In these two cases, a large part of the basin is neglected, which can explain the low correlation values.

Time shift between TWS and discharge varies from one month of advance to two months of delay (Table 4). These differences in timing can be related to the presence of floodplains in the sub-basins. For sub-basins covered with extensive floodplains (downstream part of the Andean basins, Solimões, and Mamoré), surface water is dominating TWS and the water is delayed. So the time shift is positive or equal to zero in the case of the Mamore due to the relatively small area of this sub-basin and the location of the discharge station several hundred kilometres downstream its outlet. The exceptions are the Negro and Lower Amazon basins likely due to the aforementioned problems of reconstructed river discharge and location of the gauging station. On the contrary, for the Tapajos and Xingu rivers, the runoff is not delayed through floodplains, so peak of discharge can occur before the peak of TWS.

In Figure 8, presenting the interannual variations of rainfall, TWS and discharges in the different sub-basins of the Amazon, peaks of TWS and discharges are generally in phase. For sub-basins covered with extensive floodplains (except the Negro), minima of 
discharge occur before the minima of TWS due to the stay of water in the floodplains (Figures 8b, c, g, h). Large differences can be noticed between rainfall and the other hydrological variables in 2006 and 2009 in the Andean basins (Figure 8a) at interannual time-scale. If the previously mentioned poor accuracy of satellite-derived rainfall over mountainous areas can account for these discrepancies, other factors can also be mentioned. The so-called Andean basins are composed of different basins (Marañon, Ucayali, Putumayo, and Japura) with different hydrological behaviours. They were grouped in this study because of their individual limited spatial extension with respect to the spatial resolution of GRACE products. Anomalies of rainfall or in timing of rainfall in one or several sub-basins can be responsible for concordances occurring downstream that can cause floods large enough to be detected by GRACE or to have a signature in river discharges as in 2009 , or lack of simultaneities with the opposite effect as in 2006.

\subsection{Spatio-temporal variations of rainfall and TWS}

Maps of standardized anomaly of rainfall index were computed using TRMM 3B43 rainfall product over 2003-2010 for the wet (Figure 9) and the dry seasons (Figure 10). The drought of 2005 was preceded by at least three years (2003 to 2005) of low rainfall, especially during the wet season, over the whole basin, with a minimum for 2003 caused by El Niño phenomenon, and a little recovery in 2004 due to warmer conditions in Central Pacific (Zeng et al., 2008). The negative anomalies of the standardized rainfall index were located over a large part of the basin, except the north-west and the southernmost part during the 2005 dry season, contrary to the situations in 2003 and 2004 where the negative anomalies are present over smaller regions. Its impact on TWS can be seen on maps of standardized anomaly of TWS index for the high (Figure 11) 
and low stages (Figure 12) of TWS-derived from GFZ ICA-400 km over the same time span. Low maxima of TWS were observed over the eastern part of the basin in 2003 and almost all the basin except the Tapajós and the Xingu in the south east, and the Japurá and Uaupés in the northwest in 2004, and the south of the basin in 2005. If low minima of TWS are present in some areas in the north (Uaupés and Branco, the largest tributaries to the Negro in 2003, Japurá and Uaupés in 2004) and the Mamoré in 2003 and 2004, a large region in the south, encompassing the Marañon basin (Peru), the Solimões, the Madeira (Mamoré and Lower Madeira), and the central corridor of the Amazon river exhibit large negative anomalies of $I_{T W S}$ in 2005 .

Year 2006 was characterized by above normal rainfall, especially in the north west (i.e., Japurá and Icá basins), the west (i.e., Uaupés basin) and the north (i.e., Branco basin) of the Negro basin, and the downstream part of the Lower Madeira, with the exception of the southern tributaries of the Solimões River (i.e., Purus, Juruá, and Javarí) for both rainy and wet seasons. On the contrary, 2007 was a dry year over the whole Amazon basin, with the exception of the Mamoré basin in the south, the north of the Negro basin during the wet season, and the western part of the Solimões and the north of the Negro during the dry season. Extremum of TWS were above normal in the east and the centre of the basin in 2006, and mostly negative in 2007, except the Mamoré, the Andean basins and the Negro River during high water season, the upstream part of the Solimões, and the downstream Amazon during low water season. The maxima of TWS exhibit zonal patterns in 2007 which are not present in the wet season rainfall.

$I_{R}$ presents large positive anomalies over the Andean basins, the Mamoré and the south of the Tapajos and the Xingu and negative spots over the central part of the basins during the wet season, and large positive anomalies at the junctions of the Solimões, 
Negro, and the Madeira and over the downstream part of the Lower Amazon in 2008. Maxima of TWS are very high in the Mamoré and the Tapajós, and the north of the Negro (Branco) and Lower Amazon, and low in the west of the Negro (Uaupés) during the rainy season, and minima are high in the north, and low in the south, especially in the southwest during the dry season.

Above normal (respectively below normal) rainfall are recorded along the central corridor, the Solimões and the west of the Mamoré, and the centre of the Andean basins (the north and the south of the basin, especially in the Branco, the south of the Mamoré, of the Tapajós, and of the Xingu) during the 2009 wet season. For the dry season, positive anomalies of $I_{R}$ are present in the south central and eastern parts, and negative ones especially in the north east and centre. As a consequence, very high maxima of TWS are observed over most of the basin, except above $0^{\circ}$ and below $15^{\circ} \mathrm{S}$. The minima of TWS are above normal in the south, and below normal in the north.

2010 is characterized by large negative anomalies of both rainfall and extremum of TWS over the central corridor during the rainy season and almost the whole basin during the wet season, with the exception of the north of the lower Amazon.

Correspondences are found between spatial patterns of rainfall during the wet (respectively dry) season and TWS for high (respectively low) waters, owing that a part of the differences between the two quantities can be attributed to runoff. In 2005, a large decrease in rainfall during the wet season (following two years of low rainfall) affected the south western part of the Amazon basin (Figure 9a, b and c), as reported by Marengo et al. (2008b), which caused low maxima of TWS in the Mamore, and the upstream parts of the Solimões, the Lower Madeira, and the Negro. These negative values of the $I_{T W S}$ for the maximum of the high water season (Figure 11c) are consistent 
with lower-than-the-mean discharges observed in the upper Solimões, the southern tributaries of the Solimões (Purus and Juruá), the Japurá, and the upstream of the Negro (Marengo et al., 2008a; Zeng et al., 2008; Tomasella et al., 2011). Positive and close to 0 values of $I_{T W S}$ (Figure 11c) respectively found in the centre and the east of the basin are in good agreement with above the mean and close to the mean discharge values recorded in the middle and downstream Amazon (Tomasella et al., 2011), and the water levels in Manaus $\left(-60.01^{\circ},-3.11^{\circ}\right)$ which were $1-2 \mathrm{~m}$ above normal from January to July 2005 (Marengo et al., 2008a). The spatial patterns of ITWS are also in good agreement with patterns of anomalies of surface water storage obtained using multisatellite observations during the 2005 drought ( Frappart et al., 2012).

The above normal rainfall that occurred from November 2008 to April 2009 along the central corridor of the Amazon (Figure 9g), where the rainfall are the largest (Figueroa and Nobre, 1990; Sombroek, 2001), were responsible for very high water levels (see for instance the gauge records from ORE HYBAM available at http://www.ore-hybam.org) over a large portion of the Amazon basin (Marengo et al., 2012), causing large floods. The signature of these floods can be seen in Figure $9 \mathrm{~g}$ with large positive anomalies of annual maxima occurring over the whole basin except the Caqueta (Colombia) and the Branco (northern tributary of the Negro) in the north, and the south of the Mamore, of the Tapajós, and the Xingu. These maxima were especially high $\left(I_{T W S}>1.5\right)$ all along the Solimões-Amazon mainstem and the downstream Negro, where are located the extensive floodplains, showing the importance of the storage in these hydrological reservoirs during the high water, as already reported by Frappart et al. (2008; 2011a: 2012). 
In 2010, a large deficit of precipitation during the rainy season was observed in almost all the region between $0^{\circ}$ and $-10^{\circ}$ of latitude (Figure $9 \mathrm{~h}$ ). This is consistent with what was observed at raingauges in the upper Solimões (Espinoza et al., 2011). As a consequence, $I_{T W S}$ for the annual maximum presents low values in the north of the Andean basins, and all along the Solimões-Amazon corridor, the southern tributaries of Solimões, Negro, the downstream of the Tapajós and Xingu (Figure 11h). Lower than normal discharges and water levels recorded in several locations of the Amazon basin during the high waters period (see for instance Espinoza et al., 2011 in the upper Solimões) account for a low water storage in the surface reservoir which strongly impacted on the TWS measured by GRACE.

Minima of TWS give valuable information on the spatial distribution of gain and loss of water in the soil, and, consequently, on aquifer recharge. The spatial patterns of extrema of annual deviation of the minimum of TWS (Figure 12) correspond to regions of large aquifer recharge according to the map of groundwater resources of Central and South America made available by the WHYMAP project (http://www.whymap.org). Their time variations also agree well with other hydrological and ecological parameters. For instance, the large negative $I_{R}$ values observed in the centre and the east of the basin (Figure 10c) in 2005 were followed by very low minima of TWS over the whole basin except the northwest of the Negro, and the south of the Xingu (Figure 12c). In situ measurements of water levels and discharges exhibit a similar spatial distribution of the drought intensity (Marengo et al., 2008a; Zeng et al., 2008; Tomasella et al., 2011). Very similar spatial patterns can be seen comparing the $I_{T W S}$ for the minima in 2005 with the PDSI of October 2005 (Figure 13a and b). Besides, regions of important tree mortality reported by Philipps et al. (2009) and large fire activity (Aragaõ et al., 2007; 
Zeng et al., 2008), coincide with the spatial patterns observed of minima of TWS. On the contrary, no direct relationship between extreme drought and vegetation activity can be established as previously observed with the rainfall (Saleska et al., 2007; Samanta et al., 2010).

The 2010 dry season was the driest of the period with low $I_{R}$ values all over the basin except the downstream part of the Lower Amazon (Figure 10h), causing very low minima of TWS on most of the Amazon basin (Figure 12h). These results are consistent with the extreme minima of water levels recorded all over the basin, as in Tamshiyacu in the upper Solimões (Espinoza et al., 2011), Manaus in the outlet of the Negro River, Obidos at the confluence of the Amazon and the Tapajós (Marengo et al., 2011), or at other locations of the Amazon Basin (see the ORE HYBAM website: http://www.orehybam.org). The drought of 2010 was more severe than the one of 2005 with PDSI values corresponding to severe $(-3<$ PDSI $<-4)$, extreme $(-4<$ PDSI $<-5)$, and exceptional (PDSI $<-5)$ over the western and the southern part of the basin, coinciding with the lowest minima of TWS (Figure 13c and d). The spatial patterns of the relative deviation of annual minimum of TWS also agree well with patterns of tree mortality in the south (see Lewis et al., 2011), and the widespread decline of greenness reported by $\mathrm{Xu}$ et al. (2011) in the south and the west of the basin.

\section{Conclusion}

This study provides the first analysis of the changes affecting the TWS under the recent extreme climatic events that occurred in the Amazon basin between 2003 and 2010. A good agreement (with correlation coefficient generally greater than 0.8) was found between the seasonal and the interannual variations of rainfall from TRMM 3B43 
product and GRACE-based TWS at basin and sub-basin scales. The variability of the land water storage measured by GRACE is consistent with what was observed using independent data at interannual time-scale and sub-basin spatial-scale. In particular, the spatial patterns observed in the extrema of GRACE-derived TWS are consistent not only with the ones from TRMM monthly rainfall product (this study), but also with hydrological and ecological parameters (previous studies mentioned above and this study), such as in situ river levels and discharges, anomalies of surface water maps and vegetation indexes, tree mortality, fire counts, and with PDSI. This study provides important information concerning the response of TWS to rainfall forcing at basin and sub-basin scales (i.e., the water mass storage in the hydrological reservoirs and its transport through the drainage system). Lags between the time variations of rainfall and TWS, and of TWS and rivers discharges show differences in terms of hydrological behaviour among the sub-basins related to the presence or the lack of extensive floodplains along the mainstems. Similar spatial patterns were found between rainfall and TWS at seasonal time-scale, especially for the extreme climatic events (droughts of 2005 and 2010, and flood of 2009).

These results highlight the capability of low-orbiting time-variable gravimetry missions to detect the interannual variability of land water storage and the signature of extreme climatic events such as floods and droughts. GRACE-based TWS data provide a unique source of information for the study of the hydrological cycle in ungauged basins where reliable observations of rainfall and discharges are missing. With the recent development of new methodologies to constrain regionally the recovery of continental water time-variations using GRACE data (Ramillien et al., 2012), improving the quality 
of the TWS estimates, finer-scale studies will be undertaken to characterize the relationship between rainfall and land water storage.

\section{References}

Aragaõ LEO, Malhi Y, Roman-Cuesta RM, Saatchi S, Anderson LO, Shimabukuro YE. 2007. Spatial patterns and fire response of recent Amazonian droughts. Geophysical Research Letters 34: L07701. DOI:10.1029/2006GL028946.

Asner GP, Alencar A. 2010. Drought impacts on the Amazon forest: the remote sensing perspective. New Phytologist 187: 569-578. DOI: 10.1111/j.1469-8137.2010.03310.x.

Bergmann I, Ramillien G, Frappart, F. 2012. Climate-driven interannual variations of the mass balance of Greenland. Global and Planetary Change 82-83: 1-11. DOI: 10.1016/j.gloplacha.2011.11.005.

Chen JL, Wilson CR, Tapley BD, Yang ZL, Niu GY. 2009. 2005 drought event in the Amazon River basin as measured by GRACE and estimated by climate models. Journal of Geophysical Research 114: B05404. DOI:10.1029/2008JB006056.

Chen JL, Wilson CR, Tapley BD. 2010. The 2009 exceptional Amazon flood and interannual terrestrial water storage change observed by GRACE. Water Resources Research 46(12): W12526. DOI: 10.1029/2010WR009383.

Cleveland RB, Cleveland WS, McRae JE, Terpenning I. 1990. STL: A Seasonal-Trend Decomposition Procedure Based on Loess. Journal of Official Statistics 6(1): 3-33.

Condom T, Rau P, Espinoza JC. 2011. Correction of TRMM 3B43 monthly precipitation data over the mountainous areas of Peru during the period 1998-2007. Hydrological Processes 2: 1924-1933. DOI: 10.1002/hyp.7949.

Crowley JW, Mitrovica JX, Bailey RC, Tamisiea ME, Davis J.L. 2008. Annual variations in water storage and precipitation in the Amazon Basin. Journal of Geodesy 82(1): 9-13. DOI: 10.1007/s00190-007-0153-1.

Dai A, Trenberth KE, Qian T. 2004. A global data set of Palmer Drought Severity Index for 1870-2002: Relationship with soil moisture and effects of surface warming. Journal of Hydrometeorology 5: 1117-1130.

Dai A. 2011. Characteristics and trends in various forms of the Palmer Drought Severity Index (PDSI) during 1900-2008. Journal of Geophysical Research 116: D12115, DOI:10.1029/2010JD015541.

Espinoza JC, Ronchail J, Guyot JL, Junquas C, Vauchel P, Lavado W, Drapeau G, Pombosa R. 2011. Climate variability and extreme drought in the upper Solimões River 
(western Amazon Basin): Understanding the exceptional 2010 drought. Geophysical Research Letters 38: L13406. DOI:10.102029/2011GL047862.

Espinoza JC, Ronchail J, Guyot JL, Junquas C, Drapeau G, Martinez JM, Santini W, Vauchel P, Lavado W, Espinoza R. 2012. From drought to flooding: understanding the abrupt 2010-2011 hydrological annual cycle in the upper Solimões River (Western Amazon basin). Environmental Research Letters 7: 024008. DOI:10.1088/17489326/7/2/024008

Figueroa SN, Nobre CA. 1990. Precipitions distribution over Central and Western Tropical South America. Climanálise - Boletim de Monitoramento e Análise Climática 5(6): $36-45$.

Frappart F, Papa F, Famiglietti JS, Prigent C, Rossow WB, Seyler F. 2008. Interannual variations of river water storage from a multiple satellite approach: a case study for the Rio Negro River basin. Journal of Geophysical Research 113(D21): D21104. DOI: 10.1029/2007JD009438.

Frappart F, Ramillien G, Maisongrande P, Bonnet MP. 2010. Denoising satellite gravity signals by Independent Component Analysis. IEEE Geosciences and Remote Sensing Letters 7(3): 421-425. DOI: 10.1109/LGRS.2009.2037837.

Frappart F, Papa F, Güntner A, Werth S, Santos da Silva J, Seyler F, Prigent C, Rossow WB, Calmant S, Bonnet MP. 2011a. Satellite-based estimates of groundwater storage variations in large drainage basins with extensive floodplains. Remote Sensing of Environment 115(6): 1588-1594. DOI: 10.1016/j.rse.2011.02.003.

Frappart F, Ramillien G, Leblanc M, Tweed SO, Bonnet MP, Maisongrande P. 2011b. An independent Component Analysis approach for filtering continental hydrology in the GRACE gravity data. Remote Sensing of Environment 115(1): 187-204. DOI: 10.1016/j.rse.2010.08.017.

Frappart F, Ramillien G. 2012. Contribution of GRACE satellite gravimetry in global and regional hydrology, and ice sheets mass balance. Water Resources Management and Modeling, Dr. P. Nayak (Ed.), Intech, 191-214.

Frappart F, Papa F, Santos da Silva J., Ramillien G, Prigent C, Seyler F, Calmant S. 2012. Surface freshwater storage in the Amazon basin during the 2005 exceptional drought. Environmental Research Letters, in press.

Frappart F, Papa F, Santos da Silva J, Ramillien G, Prigent C, Seyler F, Calmant S. 2012. Surface freshwater storage in the Amazon basin during the 2005 exceptional drought. Environmental Research Letters 7: 044010. DOI:10.1088/17489326/7/044010.

Han S-C, Kim H, Yeo IY, Yeh P, Oki T, Seo KW, Alsdorf D, Luthcke SB. 2009. Dynamics of surface water storage in the Amazon inferred from measurements of inter- 
satellite distance change. Geophysical Research Letters 36: L09403. DOI: 10.1029/2009GL037910.

Huffmann GJ, Adler RF, Rudolf B, Schneider U, Keehn P. 1995. Global precipitation estimates based on a technique for combining satellite-based estimates, rain gauge analysis, and NWP model precipitation information. Journal of Climate, 8, 1284-1295.

Huffmann GJ, Adler RF, Bolvin DT, Gu G, Nelkin EJ, Bowman KP, Hong Y, Stocker EF, Wolf DB. 2007. The TRMM multi-satellite precipitation analysis: quasi-global, multi-year, combined-sensor precipitation estimates at fine scale. Journal of Hydrometeorology 8(1): 38-55.

Kim H, Yeh PJF, Oki T, Kanae S. 2009. Role of rivers in the seasonal variations of terrestrial water storage over global basins. Geophysycal Research Letters 36: L17402. DOI: 10.1029/2009GL039006.

Lamb PJ. 1982. Persistence of subsaharan drought. Nature 299: 46-47.

Lavado W, Labat D, Guyot JL, Ronchail J, Ordonez J. 2009. TRMM rainfall data estimation over the Peruvian Amazon-Andes basin and its assimilation into a monthly water balance model. IAHS Publications 333: 245-252.

Lewis SL, Brando PM, Phillips OL, van der Heijden MF, Nepstad D. 2011. The 2010 Amazon drought. Science 331: 554. DOI: 10.1126/science.1200807.

Marengo JA, Nobre CA, Tomasella J, Oyama MD, Oliveira GS, de Oliveira R, Camargo H, Alves LM, Brown IF. 2008a. The drought of Amazonia in 2005. Journal of Climate 21: 495-516. DOI: 10.1175/2007JCLI1600.1.

Marengo JA, Nobre CA, Tomasella J., Cardoso MF, Oyama MD. 2008b. Hydroclimatic and ecological behaviour of the drought of Amazonia in 2005. Philosphical Transactions of the Royal Society of London, Series B, Biological Sciences B363: 19111916. DOI: 10.1098/rstb.2007.0023.

Marengo JA, Tomasella J, Alves LM, Soares WA, Rodriguez DA. 2011. The drought of 2010 in the context of historical droughts in the Amazon region. Geophysical Research Letters 38: L12703. DOI: 10.1029/2011GL047436.

Marengo JA, Tomasella J, Soares WR, Alves LM, Nobre CA. 2012. Extreme climatic events in the Amazon basin: Climatological and hydrological context of recent floods. Theoretical and Applied Climatology 107: 73-85. DOI: 10.1007/s00704-011-0465-1.

Papa F, Güntner A, Frappart F, Prigent C, Rossow WB. 2008. Variations of surface water extent and water storage in large river basins: A comparison of different global data sources. Geophysical Research Letters 35(11): L11401. DOI: 10.1029/2008GL033857. 
Philipps OL et al. 2009. Drought sensitivity of the Amazon rainforest. Science 323: 1344-1347. DOI: 10.1126/science.1164033.

Ramillien G, Frappart F, Güntner A, Ngo-Duc T, Cazenave A, Laval K. 2006. Timevariations of the regional evapotranspiration rate from Gravimetry Recovery And Climate Experiment (GRACE) satellite gravimetry. Water Resources Research 42: W10403. DOI: 10.1029/2005WR004331.

Ramillien G, Famiglietti JS, Wahr J. 2008. Detection of continental hydrology and glaciology signals from GRACE: a review. Surveys in Geophysics 29: 361-374. DOI: 10.1007/s10712-008-9048-9.

Ramillien G, Seoane L, Frappart F, Biancale R, Gratton S, Vasseur X, Bourgogne S. 2012. Constrained regional recovery of continental water mass time-variations from GRACE-based geopotential anomalies over South America. Surveys in Geophysics 33(5): 887-905. DOI: 10.1007/s10712-012-9177-z.

Saleska SR, Didan K, Huete AR, da Rocha AR. 2007. Amazon forests green-up during 2005 drought. Science 318: 612. DOI: 10.1126/science.1146663.

Samanta A, Ganguly S, Hashimoto H, Devadiga S, Vermote E, Knyazikhin Y, Nemani RR, Myneni RB. 2010. Amazon forests did not green-up during the 2005 drought. Geophysical Research Letters 37: L05401. DOI: 10.1029/2009GL042154.

Schmidt R, Flechtner F, Meyer U, Neumayer KH, Dahle C, Koenig R, Kusche J. 2008. Hydrological Signals Observed by the GRACE Satellites. Surveys in Geophysics 29: 319-334. DOI: 10.1007/s10712-008-9033-3.

Seyler F, Muller F, Cochonneau G, Guimarães L, Guyot JL. 2009. Watershed delineation for the Amazon sub-basin system using GTOPO30 DEM and a drainage network extracted from JERS SAR images. Hydrological Processes 23(22): 3173-3185.

Sombroek W. 2001. Spatial and temporal patterns of Amazon rainfall. Consequences for the planning of agricultural occupation and the protection of primary forests. Ambio 30(7): 388-396.

Tomasella J, Borma LS, Marengo JA, Rodriguez DA, Cuartas LA, Nobre CA, Prado MCR. 2011. The droughts of 1996-1997 and 2004-2005 in Amazonia: hydrological response in the river main-stem. Hydrological Processes 25: 1228-1242, doi: 10.1002/hyp.7889.

Xavier L, Becker M, Cazenave A, Longuevergne L, Llovel W, Rotunno Filho OC. 2010. Interannual variability in water storage over 2003-2008 in the Amazon Basin from GRACE space gravimetry, in situ river level and precipitation data. Remote Sensing of Environment 114: 1629-1637. 
Xu L, Samanta A, Costa MH, Ganguly S, Nemani RR, Myneni RB. 2011. Widespread decline in greenness of Amazonian vegetation due to the 2010 drought. Geophysical Research Letters 38: L07402. DOI: 10.1029/2011GL046824.

Wahr J, Molenaar M, Bryan F. 1998. Time variability of the Earth's gravity field: Hydrological and oceanic effects and their possible detection using GRACE. Journal of Geophysical Research 103(B3): 30,205-30,229.

Zeng N, Yoon JH, Marengo JA, Subramaniam A, Nobre CA, Mariotti A, Neelin JD. 2008. Causes and impacts of the 2005 Amazon drought. Environmental Research Letters 3: 014002, doi: 10.1088/1748-9326/014002. 


\section{Tables}

Table 1 : Area of the Amazon basin and of the 8 sub-basins.

\begin{tabular}{lr} 
Basin & Area $\left(\mathrm{km}^{2}\right)$ \\
\hline Amazon & $6,003,500$ \\
\hline Andean basins & $1,221,000$ \\
\hline Solimões & $1,027,600$ \\
\hline Mamoré & 917,500 \\
\hline Lower Madeira & 443,700 \\
\hline Negro & 736,900 \\
\hline Tapajos & 463,300 \\
\hline Xingu & 501,400 \\
\hline Lower Amazon & 680,700
\end{tabular}


Table 2 : Locations and availability of the in situ discharge stations used in this study.

\begin{tabular}{|c|c|c|c|c|c|}
\hline Station & Longitude $\left(^{\circ}\right)$ & Latitude $\left(^{\circ}\right.$ & Basin & Availability & Source \\
\hline Tabatinga & -69.952 & -4.253 & Andean basins & $01 / 2002-07 / 2011$ & Hybam \\
\hline Manacapuru & -60.609 & -3.316 & Solimões & $01 / 2002-07 / 2011$ & Hybam \\
\hline Porto Velho & -63.9460 & -8.7997 & Lower Madeira & $01 / 2002-07 / 2011$ & Hybam \\
\hline$\overline{\text { Fazenda Vista }}$ & -60.026 & -4.898 & & $01 / 2002-07 / 2011$ & \\
\hline Alegre & & & Lower Madeira & & Hybam \\
\hline Jatuarana & -59.643 & -3.062 & Lower Amazon & $01 / 2002-07 / 2011$ & ANA \\
\hline Itaituba & -55.982 & -4.278 & Tapajos & $01 / 2002-07 / 2011$ & Hybam \\
\hline Altamira & -52.03 & -3.03 & Xingu & $01 / 2002-02 / 2009$ & ANA \\
\hline Obidos & -55.6753 & -1.9225 & Lower Amazon & $01 / 2002-07 / 2011$ & Hybam \\
\hline
\end{tabular}


Table 3: Maximum correlation between monthly rainfall from TRMM 3B43 and GRACE-based monthly anomalies of TWS post-processed using a Gaussian filter of $400 \mathrm{~km}$ of radius and ICA approach from GFZ and the corresponding time-lags in months. p-values are lower than 0.01 for all the basins.

\begin{tabular}{|c|c|c|c|c|}
\hline \multirow[t]{2}{*}{ Basin } & \multicolumn{2}{|c|}{$\begin{array}{l}\text { Maximum correlation between } \\
\text { rainfall and TWS } \\
\text { and } 95 \% \text { confidence interval }\end{array}$} & \multicolumn{2}{|c|}{$\begin{array}{l}\text { Corresponding time-lag } \\
\text { (months) }\end{array}$} \\
\hline & Total & Interannual & Total & Interannual \\
\hline Amazon & $\begin{array}{c}0.93 \\
(0.90-0.95)\end{array}$ & $\begin{array}{c}0.81 \\
(0.73-0.87)\end{array}$ & 2 & 3 \\
\hline Andean basins & $\begin{array}{c}0.68 \\
(0.56-0.79)\end{array}$ & $\begin{array}{c}0.47 \\
(0.29-0.61)\end{array}$ & 2 & 3 \\
\hline Solimões & $\begin{array}{c}0.92 \\
(0.88-0.94)\end{array}$ & $\begin{array}{c}0.91 \\
(0.86-0.93)\end{array}$ & 2 & 3 \\
\hline Mamoré & $\begin{array}{c}0.88 \\
(0.83-0.92)\end{array}$ & $\begin{array}{c}0.67 \\
(0.54-0.77)\end{array}$ & 2 & 3 \\
\hline Lower Madeira & $\begin{array}{c}0.91 \\
(0.87-0.92)\end{array}$ & $\begin{array}{c}0.82 \\
(0.75-0.88)\end{array}$ & 2 & 2 \\
\hline Negro & $\begin{array}{c}0.78 \\
(0.69-0.85)\end{array}$ & $\begin{array}{c}0.74 \\
(0.63-0.82)\end{array}$ & 1 & 2 \\
\hline Tapajos & $\begin{array}{c}0.88 \\
(0.82-0.92)\end{array}$ & $\begin{array}{c}0.76 \\
(0.65-0.83) \\
\end{array}$ & 2 & 3 \\
\hline Xingu & $\begin{array}{c}0.87 \\
(0.81-0.91)\end{array}$ & $\begin{array}{c}0.77 \\
(0.66-0.84)\end{array}$ & 2 & 3 \\
\hline Lower Amazon & $\begin{array}{c}0.89 \\
(0.84-0.93)\end{array}$ & $\begin{array}{c}0.83 \\
(0.75-0.88)\end{array}$ & 2 & 2 \\
\hline
\end{tabular}


Table 4: Maximum correlation between GRACE-based monthly anomalies of TWS post-processed using a Gaussian filter of $400 \mathrm{~km}$ of radius and ICA approach from GFZ and the difference between river discharges inflow and outflow the corresponding timelags in months. p-values are lower than 0.01 for all the basins. * Monthly discharge in Manaus has been computed as the difference monthly discharges in Jatuarana and Manacapuru.

\begin{tabular}{|c|c|c|c|c|c|}
\hline \multirow[t]{2}{*}{ Basin } & \multirow[t]{2}{*}{$\begin{array}{l}\text { River } \\
\text { Inflow- } \\
\text { Outflow }\end{array}$} & \multicolumn{2}{|c|}{$\begin{array}{l}\text { Maximum correlation between } \\
\text { TWS and discharge and } 95 \% \\
\text { confidence interval }\end{array}$} & \multicolumn{2}{|c|}{$\begin{array}{l}\text { Corresponding } \\
\text { time-lag (months) }\end{array}$} \\
\hline & & Total & Interannual & Total & Interannual \\
\hline Amazon & up to Obidos & $\begin{array}{c}0.96 \\
(0.93-0.97) \\
\end{array}$ & $\begin{array}{c}0.94 \\
(0.92-0.96) \\
\end{array}$ & 1 & 1 \\
\hline Andean basins & $\begin{array}{c}\text { up to } \\
\text { Tabatinga }\end{array}$ & $\begin{array}{c}0.88 \\
(0.83-0.92)\end{array}$ & $\begin{array}{c}0.87 \\
(0.81-0.91) \\
\end{array}$ & 0 & 1 \\
\hline Solimões & $\begin{array}{c}\text { Tabatinga - } \\
\text { Manacapuru }\end{array}$ & $\begin{array}{c}0.89 \\
(0.84-0.93)\end{array}$ & $\begin{array}{c}0.95 \\
(0.95-0.97) \\
\end{array}$ & 2 & 1 \\
\hline Mamoré & $\begin{array}{l}\text { up to Porto } \\
\text { Velho }\end{array}$ & $\begin{array}{c}0.97 \\
(0.96-0.98) \\
\end{array}$ & $\begin{array}{c}0.95 \\
(0.92-0.97) \\
\end{array}$ & 0 & 0 \\
\hline Lower Madeira & $\begin{array}{l}\text { Porto Velho - } \\
\text { Fazenda } \\
\text { Vista Alegre } \\
\end{array}$ & $\begin{array}{c}0.91 \\
(0.87-0.94)\end{array}$ & $\begin{array}{c}0.59 \\
(0.44-0.71)\end{array}$ & 0 & 0 \\
\hline Negro & $\begin{array}{c}\text { up to } \\
\text { Manaus* }\end{array}$ & $\begin{array}{c}0.72 \\
(0.60-0.80)\end{array}$ & $\begin{array}{c}0.76 \\
(0.65-0.83) \\
\end{array}$ & -1 & -1 \\
\hline Tapajos & up to Itaituba & $\begin{array}{c}0.92 \\
(0.89-0.95) \\
\end{array}$ & $\begin{array}{c}0.89 \\
(0.84-0.93) \\
\end{array}$ & -1 & -1 \\
\hline Xingu & $\begin{array}{c}\text { up to } \\
\text { Altamira }\end{array}$ & $\begin{array}{c}0.90 \\
(0.85-0.94)\end{array}$ & $\begin{array}{c}0.85 \\
(0.77-0.90)\end{array}$ & 0 & -1 \\
\hline Lower Amazon & $\begin{array}{l}\text { Obidos - } \\
\text { Jatuarana }\end{array}$ & $\begin{array}{c}0.80 \\
(0.81-0.91)\end{array}$ & $\begin{array}{c}0.63 \\
(0.49-0.74) \\
\end{array}$ & -1 & -2 \\
\hline
\end{tabular}




\section{Figures}

Figure 1: Map of the Amazon basin and of its 8 sub-basins: Andean basins (dark blue), Negro basin (dark green), Solimões (grey), Mamoré (light green), Lower Madeira (yellow), Lower Amazon (orange), Tapajós (red), Xingu (brown). In situ stations of river discharges are located using black circles (Manaus is underlined as no measurement is achieved here, but monthly discharges were reconstructed for the Negro basin by difference between discharges in Jatuarana and Manacapuru).

Figure 2 : Times series of a) monthly rainfall from TRMM 3B43, and b) GRACEbased TWS post-processed using a Gaussian filter of $400 \mathrm{~km}$ of radius and ICA approach from CSR (blue), GFZ (green), and JPL (red), and associated interannual trends from STL decomposition (dotted lines), from 2003 to 2010 over the Amazon basin.

Figure 3: Times series of monthly rainfall from TRMM $3 \mathrm{~B} 43$ and associated interannual trends from STL decomposition (dotted lines), from 2003 to 2010 over a) Andean basins, b) Solimões, c) Mamoré, d) Lower Madeira, e) Tapajos, f) Xingu, g) Negro, and h) Lower Amazon sub-basins.

Figure 4 : Times series of monthly rainfall from GRACE-based TWS post-processed using a Gaussian filter of $400 \mathrm{~km}$ of radius and ICA approach from CSR (blue), GFZ (green), and JPL (red), and associated interannual trends from STL decomposition (dotted lines), from 2003 to 2010 over a) Andean basins, b) Solimões, c) Mamoré, d) Lower Madeira, e) Tapajos, f) Xingu, g) Negro, and h) Lower Amazon sub-basins.

Figure 5: Time variations of the standardized rainfall anomaly index from TRMM 3B43 rainfall product between 2003 and 2010 over north Amazonia during the a) wet and the b) dry seasons, and south Amazonia during the c) wet and the d) dry seasons.

Figure 6: Time variations of the standardized TWS anomaly index from GRACE (GFZ ICA $400 \mathrm{~km}$ ) between 2003 and 2010 over north Amazonia for a) high and b) low storages, and south Amazonia for c) high and d) low storages.

Figure 7: Scatterplots between monthly rainfall from TRMM 3B43 and GRACE-based monthly anomalies of TWS during the period 2003-2010 over a) Andean basins, b) Solimões, c) Mamoré, d) Lower Madeira, e) Tapajos, f) Xingu, g) Negro, and h) Lower Amazon sub-basins.

Figure 8: Time-series of interannual variations of monthly rainfall from TRMM 3B43 (grey), GRACE-based monthly anomalies of TWS (blue: CSR, green: GFZ, red: JPL), and monthly discharge (black) during the period 2003-2010 over a) Andean basins (discharge station: Tabatinga), b) Solimões, c) Mamoré, d) Lower Madeira, e) Tapajos, f) Xingu, g) Negro, and h) Lower Amazon sub-basins.

Figure 9: Standardized rainfall anomaly index from TRMM 3B43 for the wet season over the Amazon basin during the period 2003-2010. 
Figure 10: Standardized rainfall anomaly index from TRMM 3B43 for the dry season over the Amazon basin during the period 2003-2010.

Figure 11: Standardized annual maximum of TWS from GRACE (GFZ ICA $400 \mathrm{~km}$ ) over the period 2003-2010.

Figure 12: Standardized annual minimum of TWS from GRACE (GFZ ICA $400 \mathrm{~km}$ ) over the period 2003-2010.

Figure 13: Standardized annual minimum of TWS from GRACE (GFZ ICA $400 \mathrm{~km}$ ) for a) 2005, b) 2010, and Palmer Drought Severity Index for b) October 2005, d) October 2010. 